\title{
Investigation and Water quality Analysis of Agricultural non- point Source pollution in Tanxia Town
}

\author{
Liya Yang ${ }^{1,2,3, *}$, Hao Zhou ${ }^{1}$, Liyuan Dai ${ }^{1,3}$ \\ ${ }^{1}$ Wanjiang University of Technology, Maanshan, 243031, China \\ ${ }^{2}$ Ma'anshan Engineering Technology Research Center of Engineering Monitoring and Safety Monitoring China \\ ${ }^{3}$ Maanshan Engineering Technology Research Center for Water Resources Efficient Utilization in Hilly Region China
}

\begin{abstract}
Taking the small watershed in Tanxia town as an example, the classified investigation of agricultural non-point source pollution in the tributaries of Lijiang River was carried out, the sources of local agricultural non-point source pollution were analyzed, and the surface water environmental quality standard and Nemero index method were used to evaluate the water quality of the basin. The results show that the water quality of the basin is poor and the pollution exceeds the standard all the year round, and the source of agricultural non-point source pollution mainly depends on the pollution of agricultural chemical fertilizer. Improving the use of local chemical fertilizer and rational application of chemical fertilizer are the key factors to improve local agricultural non-point source pollution.
\end{abstract}

Keywords: Non-point source pollution, Chemical fertilizer, Tanxia Town.

\section{Introduction}

The amendment to the Clean Water Act of the United States in the last century defines non-point source pollution as a source of pollution that enters surface and underground water bodies in a wide, dispersed and trace form. With the rapid development of economy, non-point source pollution has become the main source of agricultural pollution. As a large agricultural country, the severe situation of non-point source pollution in rural areas is not optimistic. Due to the abuse of chemical fertilizers and pesticides, agricultural non-point source pollution can't be controlled reasonably and effectively.

At present, the situation of water pollution in the Lijiang River basin is not optimistic. Agricultural non-point source pollution directly affects the ecological environment and drinking water safety in the Lijiang River basin. Taking Tanxia Town as an example, this paper studies the current situation of agricultural non-point source pollution in the tributary basin of the Lijiang River, provides a powerful tool for the study of non-point source pollution, has potential application value, and is of great significance to the construction of ecological civilization..

\section{Background}

Tanxia Town is located in the northwest of Lingchuan County, $18 \mathrm{~km}$ from the urban area of Guilin, the river basin belongs to the Lijiang River basin, the river runs through many villages in the town, the full-length $8 \mathrm{~km}$, the basin area $12 \mathrm{~km}^{2}$. Tanxia Town is located in the mid-subtropical monsoon climate zone, with four distinct seasons, abundant rainfall and hot rain in the same season, which is conducive to the growth of all kinds of crops. The average annual rainfall is $1941.5 \mathrm{~mm}$ and the annual average temperature is $18.7^{\circ} \mathrm{C}$. The content of organic matter in the soil in the study area is less, the content of nitrogen, phosphorus and potassium is less, and the fertility is low. The regional vegetation cover is good, reaching more than $70 \%$. As an important grain production base in Guangxi, the town has 3320 hectares of cultivated land and 2.3 million $\mathrm{mu}$ of orchards.

\subsection{Sources of agricultural non-point source pollution}

The population income of Tanxia town is mainly agriculture, forestry, animal husbandry, fishery and so on. There are no industrial factories in this survey area. The sources of non-point source pollution in the basin are mainly concentrated in agricultural pollution, and the contents of this survey mainly include rural population, the amount of agricultural chemical fertilizer, insecticidal dose, livestock breeding, the content of pollutants in the basin and so on.

Through the collection of data, on-the-spot investigation and household inquiry, nine villages in the research basin of Tanxia Town were investigated, and the basic situation of local farmers' population, planting, breeding and

*Corresponding author: 527615613@qq.com 
domestic sewage discharge in 2013 were investigated by questionnaire.

\subsection{Rural domestic sewage}

The discharge of domestic sewage from rural residents and the excretion of local residents are the main sources of non-point source pollution in rural areas. This survey counted the number of local residents and monitored the water quality around the residential toilets, and calculated the total load of rural domestic sewage as shown in Table 1. Among them, the content of pollutants in human feces and urine is determined by the research regulations of the National Health Bureau, which stipulates that the emission coefficient of total nitrogen is $0.584 \mathrm{~kg}$ per person per year, and the emission coefficient of ammonia nitrogen is $0.16 \mathrm{~kg}$ per person per year. The average discharge of feces and urine per person per day is $250 \mathrm{~g}$ and $1000 \mathrm{~g}$ respectively.

Table 1. Statistical data unit of rural domestic pollution

\begin{tabular}{ccl}
\hline Project & $\mathrm{TN}$ & $\mathrm{NH}_{3}-\mathrm{N}$ \\
\hline Feces & $730 \mathrm{~kg}$ & $200 \mathrm{~kg}$ \\
\hline Urine & $2920 \mathrm{~kg}$ & $800 \mathrm{~kg}$ \\
\hline
\end{tabular}

\subsection{Pesticides and fertilizers}

The main crops in the study area are rice and citrus. This survey visited seven villages in the study area, according to the results of field investigation, combined with the results of the 2016 national survey of pollution sources in Guilin, to determine the application amount of pesticides and chemical fertilizers per unit area in the basin, as shown in Table 2 below.

Table 2. Application rate of pesticides and chemical fertilizers

\begin{tabular}{cccc}
\hline & & \multicolumn{2}{c}{$\begin{array}{c}\text { Chemical fertilizer } \\
(\mathrm{kg} / \mathrm{mu})\end{array}$} \\
\cline { 3 - 4 } Position & $\begin{array}{c}\text { Pesticide(kg/ } \\
\text { mu })\end{array}$ & $\begin{array}{c}\text { Compou } \\
\text { nd } \\
\text { fertilizer } \\
(\mathrm{kg} / \mathrm{mu})\end{array}$ & $\begin{array}{c}\mathrm{Urea}(\mathrm{kg} / \mathrm{m} \\
\mathrm{u})\end{array}$ \\
\hline $\begin{array}{c}\text { Gan } \\
\text { Village }\end{array}$ & 0.07 & 100 & 60 \\
\hline $\begin{array}{c}\text { Jiang } \\
\text { family }\end{array}$ & 0.07 & 80 & 60 \\
\hline Huangbai & 0.05 & 110 & 70 \\
\hline Cha futian & 0.08 & 100 & 75 \\
\hline $\begin{array}{c}\text { Shangliyu } \\
\text { an }\end{array}$ & 0.1 & 100 & 50 \\
\hline Xialiyuan & 0.095 & 100 & 50 \\
\hline Xinqiao & 0.1 & 150 & 75 \\
\hline Average & 0.08 & 105.7 & 62.9 \\
\hline
\end{tabular}

The rice in the study area is two seasons a year, the amount of compound fertilizer per season is $10 \sim 20 \mathrm{~kg} / \mathrm{mu}$, three times per season, each time decreasing $3 \sim 5 \mathrm{~kg}$ per $\mathrm{mu}$, urea application rate is $5 \sim 10 \mathrm{~kg} / \mathrm{mu}$, fertilizing twice per season, each time decreasing 1 2kg per mu. Citrus is fertilized about 3 times a year, the amount of compound fertilizer per mu is about $10 \mathrm{~kg}$, and the amount of urea per $\mathrm{mu}$ is about $5 \mathrm{~kg}$.

\subsection{Pollution caused by livestock faeces}

The livestock and poultry found in the study area are mainly pigs, chickens and ducks. In the process of breeding, the manure of livestock and poultry is an important source of agricultural non-point source pollution. A small amount of livestock and poultry manure can be used as organic fertilizer in agricultural production and is absorbed by crops. if the scale of livestock and poultry breeding is large, a large amount of manure is bound to cause some pollution to the environment. Precipitation scours the untreated livestock manure, making the livestock manure accumulated around the farm flow into the water body with the water flow, causing pollution to the river.

The excretion of feces and urine of livestock and poultry is related to many factors, such as animal species, growth cycle, feed and so on, but the effect on the result is not obvious. With reference to the calculation method in the Fertilizer Handbook and combined with the data, Table 3 was selected as the pollutant parameter of livestock and poultry manure in the study area.

Table 3. Average content of pollutants in livestock and poultry faeces per

\begin{tabular}{ccccc}
\hline Project & $\begin{array}{c}\text { Pig } \\
\text { manure }\end{array}$ & $\begin{array}{c}\text { Pig } \\
\text { urine }\end{array}$ & $\begin{array}{c}\text { Chicken } \\
\text { manure }\end{array}$ & $\begin{array}{c}\text { Duck } \\
\text { manure }\end{array}$ \\
\hline $\mathrm{TN}$ & 5.88 & 3.3 & 9.84 & 11 \\
\hline $\mathrm{NH}_{3}-\mathrm{N}$ & 3.1 & 1.4 & 4.78 & 0.8 \\
\hline
\end{tabular}

\subsection{Water pollution.}

According to the location of the watershed in the study area, this paper selects Gan village outlet, Chaibutian, Huangbai, Xinqiao North, Huangbai Village Trading Market, Donggang Canal, Shangliyuan and Guanli as water quality monitoring points. The water sample data of 8 months from September 2013 to April 2014 are tested, the outliers are removed, and the average value is taken. The test results are as follows:

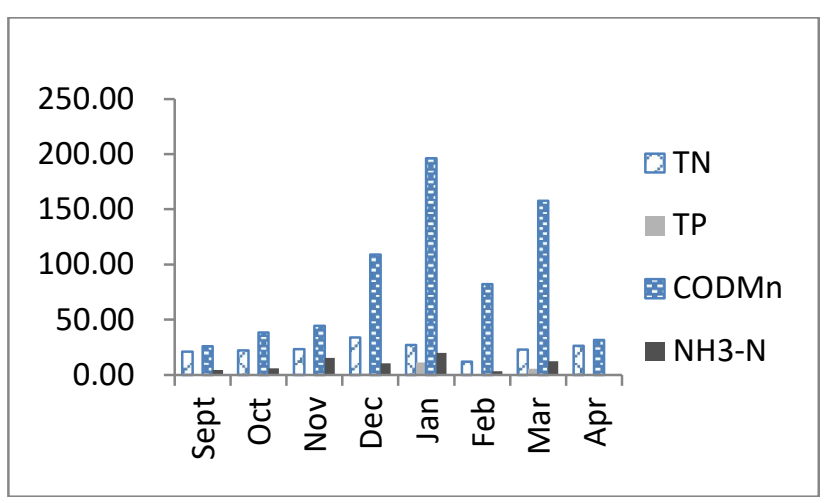

Fig. 1 Monthly average concentration of pollutants 
The Environmental Quality Standards in Surface Water and the Sanitary Standard of Water for domestic Application by the Ministry of Health in 2001. According to the function and standard of water area, surface water is divided into five types. The functions of the five types of water are decreasing in turn, of which Class I II and Class III are mainly suitable for drinking water, IV water can only be used as general industrial water, and Class V water is only suitable for general landscape waters. The source of water in the basin has drinking water requirements, so the environmental quality standards of surface water in the basin should meet the requirements of III or above.

Table 4. Environmental Quality Standards in Surface Water

\begin{tabular}{cccccc}
\hline $\begin{array}{c}\text { Project(mg/ } \\
\text { L) }\end{array}$ & $\begin{array}{c}\text { Clas } \\
\text { s I }\end{array}$ & $\begin{array}{c}\text { Clas } \\
\text { s II }\end{array}$ & $\begin{array}{c}\text { Clas } \\
\text { s III }\end{array}$ & $\begin{array}{c}\text { Clas } \\
\text { sIV }\end{array}$ & $\begin{array}{c}\text { Clas } \\
\text { s V }\end{array}$ \\
\hline $\mathrm{TN}$ & 0.2 & 0.5 & 1.0 & 1.5 & 2.0 \\
\hline $\mathrm{TP}$ & 2 & 4 & 6 & 10 & 15 \\
\hline $\mathrm{COD}_{\mathrm{Mn}}$ & 0.02 & 0.1 & 0.2 & 0.3 & 0.4 \\
\hline $\mathrm{NH}_{3}-\mathrm{N}$ & 0.15 & 0.5 & 1.0 & 1.5 & 2.0 \\
\hline
\end{tabular}

\section{Evaluation of water quality.}

At present, because the single factor index method is simple to calculate and reflect intuitively as a more common calculation method in water quality evaluation, but its disadvantage is that it can not fully reflect the comprehensive situation of water environment pollution, and the results are not representative. In order to make the evaluation results comprehensive, this paper uses the Nemero comprehensive pollution index method to evaluate the water quality of the river basin, and the improved Nemero comprehensive index method takes into account the impact of pollution factors with lower concentration on the environment. Not only consider the impact of pollution factors with the largest pollution index. This makes the result of the evaluation more accurate. In this paper, the measured concentration of monitoring index and the reference value of III water are selected as the standard concentration. The specific calculation formula is as follows:

$$
\begin{gathered}
F_{i}=\frac{c_{i}}{s_{i}} \\
P_{i}=\frac{\sqrt{F_{\text {max }}^{2}+\bar{F}}}{2} \\
\bar{P}=\frac{1}{n} \sum_{i=1}^{n} P_{i}
\end{gathered}
$$

$C_{i}$ is the measured concentration, $S_{i}$ is the standard concentration, $P_{i}$ is the cross-section Merro index, $P_{s}$ is the weighted average Nemero index.

The corresponding relationship between Nemero index and water quality grade is shown in Table 5.
Table 5. The corresponding relationship between Nemero index and water quality grade

\begin{tabular}{cccccc}
\hline $\begin{array}{c}\text { Water } \\
\text { quality } \\
\text { category }\end{array}$ & $\begin{array}{c}\text { Class } \\
\text { I }\end{array}$ & $\begin{array}{c}\text { Class } \\
\|\end{array}$ & $\begin{array}{c}\text { Class } \\
\text { III }\end{array}$ & $\begin{array}{c}\text { Cla } \\
\text { ssIV }\end{array}$ & $\begin{array}{c}\text { Class } \\
\text { V }\end{array}$ \\
\hline $\begin{array}{c}\text { Nemero } \\
\text { index }\end{array}$ & $\begin{array}{c}\mathrm{P}<0.5 \\
0\end{array}$ & $\begin{array}{c}0.59 \leq \\
\mathrm{P}<0.7\end{array}$ & $\begin{array}{c}0.74 \leq \\
\mathrm{P}<1.0 \\
0\end{array}$ & $\begin{array}{c}1.00 \\
\leq \mathrm{P}<\end{array}$ & $\begin{array}{c}\mathrm{P} \geq 3.5 \\
0\end{array}$ \\
\hline
\end{tabular}

According to the measured data, the water quality in this

\begin{tabular}{|c|c|c|c|c|c|c|}
\hline \multicolumn{5}{|c|}{ Nemero index } & \multirow{2}{*}{$\begin{array}{l}\text { Weighted } \\
\text { average } \\
\text { Nemero } \\
\text { index }\end{array}$} & \multirow{2}{*}{$\begin{array}{c}\text { Water } \\
\text { quality } \\
\text { category }\end{array}$} \\
\hline Month & $\mathrm{TN}$ & $\mathrm{TP}$ & $\mathrm{COD}_{\mathrm{Mn}}$ & $\begin{array}{c}\mathrm{NH}_{3}- \\
\mathrm{N}\end{array}$ & & \\
\hline Sept & 0.97 & 0.96 & 0.46 & 2.59 & 1.25 & IV \\
\hline Oct & 1.08 & 0.73 & 0.77 & 2.49 & 1.27 & IV \\
\hline Nov & 3.18 & 3.10 & 7.35 & 3.44 & 4.27 & $\mathrm{~V}$ \\
\hline Dec & 3.21 & 3.21 & 2.09 & 2.76 & 2.82 & IV \\
\hline Jan & 0.00 & 0.00 & 0.00 & 0.00 & 0.00 & - \\
\hline Feb & 0.00 & 0.00 & 0.00 & 3.79 & 0.95 & III \\
\hline Mar & 2.25 & 1.65 & 0.00 & 16.14 & 5.01 & $\mathrm{~V}$ \\
\hline Apr & 2.42 & 2.33 & 1.98 & 4.21 & 2.73 & IV \\
\hline
\end{tabular}
area is calculated as follows:

Table 6. Water quality evaluation results

\section{Discussion.}

In recent years, with the attention to the problem of nonpoint source pollution in China, the domestic non-point source pollution model will also be established. The research on non-point source pollution model is still in its infancy. With the effective control of point source pollution, the treatment of non-point source pollution will improve the problem of agricultural non-point source pollution in China.

According to the Nemero index method, the water quality in November and March is the worst, and the water quality in February is relatively good. The monitoring data show that except for the accident of total phosphorus, the contents of total nitrogen, permanganate index and ammonia nitrogen in surface water are much higher than the standard concentration of surface water. Among them, the change of the content of pollutants in the water body will show an irregular "W" shape with the month.

Generally speaking, the main source of surface water pollution in small watersheds is caused by chemical fertilizers and pesticides in local agricultural cultivation. According to the investigation, the seasonal characteristics of fertilizer application in the watershed were obtained, and considering the delay of the migration and transformation of pollution factors with rainfall and runoff, it was found that there was a certain coincidence between the time of concentrated application of fertilizer and the period when the concentration of pollutants exceeded the standard. it is proved that there is a certain relationship between the content of pollutants in water and the excessive application of local pesticides and fertilizers. The intensity of rainfall and the amount of rainfall also have a certain impact on the concentration of pollutants in the basin. 
Because the soil in the basin itself is not fertile, the high demand of local farmers for crop yield has led to a relatively high content of pollutants in the basin. Blind fertilization is not the only way to increase yield. The government should increase the relevant training for farmers in scientific and rational planting and breeding in order to improve the deterioration of the local water resources environment.

\section{Acknowledgments}

This work was financially supported by scientific research projests of Maanshan Engineering Technology Research Center for Water Resources Efficient Utilization in Hilly Region (WREU202102), scientific research projests of Ma'anshan Engineering Technology Research Center of Engineering Monitoring and Safety Monitoring (2020gcjc02) and The Program of Cultivating University Top-Notch Talents (gxyg2021244) fund.

\section{References}

1. El Behairy Radwa A.,El Baroudy Ahmed A.,Ibrahim Mahmoud M.,Kheir Ahmed M. S.,Shokr Mohamed S.. Modelling and Assessment of Irrigation Water Quality Index Using GIS in Semi-arid Region for Sustainable Agriculture[J]. Water, Air, \& Soil Pollution,2021,232(9):

2. Li Donglin,Zhang Hucai,Chang Fengqin,Duan Lizeng,Zhang Yang. Distribution and healthecological risk assessment of heavy metals: an endemic disease case study in southwestern China.[J]. Environmental science and pollution research international,2021:

3. Xiang Meng, Gu Shixiang, Gao Rong, Xie Chongbao, Cui Yuanlai. Investigation of farmland non-point Source and Countermeasures of Agricultural Water Saving and Emission reduction in Qilu Lake Basin [J]. China Rural Water Conservancy and Hydropower, 2021 (08): 127,132.

4. Hu Yawei, Ma Qiang, Zhai Laizheng, Jin Xiaohui. Calculation of agricultural non-point source pollution load in Yellow River diversion irrigation area based on SWAT $[\mathrm{J} / \mathrm{OL}]$. Ecological environment monitoring of the three Gorges: 1-22 [2021-10-07].

5. You Ruyue, ao Tianqi, Zhu Hong, Gao Danyang, Zhang Xing. Comparative study on evaluation methods of water quality in small watershed [J]. Sichuan Environment, 2021 and 40 (02): 73-81.

6. Zang Mengyuan, Li Ying. Study on load estimation and Control Countermeasures of Agricultural nonpoint Source pollution [J]. Shandong Agricultural Sciences, 2021, 53 (02): 142-147.

7. Zhang Caili, Lin Lin, Jiang Yi, Lu Kai. Study on the variation characteristics and influencing factors of water quality in Huaihe River Basin (Fuyang section) from 2009 to 2018 [J]. Anhui Agricultural Sciences, 2020,48,23: 95-100,107.
8. Li Su, Yan Zhihong, Xu Dan, Wang Shuqian. Application of improved Nemero Index method in Reservoir Water quality Evaluation $[\mathrm{J}]$. Science, Technology and Engineering, 20205,20 (31): 1307913084.

9. You Ruyue, ao Tianqi, Zhu Hong, Gao Danyang, Zhang Xing. Comprehensive Assessment of Water Environment pollution in Xiaoanxi Watershed [J]. Hydropower, 2020, 46 (11): 6-10, 64. 